\title{
Clock Device
}

National Cancer Institute

\section{Source}

National Cancer Institute. Clock Device. NCI Thesaurus. Code C49874.

A device designed to indicate the time of day or to measure the time duration of an event or action. 